\title{
C5-Amino acid functionalized LNA: positively poised for antisense applications $\uparrow$
}

Cite this: Chem. Commun., 2014 50, 9007

Received 13th May 2014

Accepted 10th June 2014

DOI: $10.1039 / c 4 c c 03623 a$

www.rsc.org/chemcomm

Incorporation of positively charged C5-amino acid functionalized LNA uridines into oligodeoxyribonucleotides (ONs) results in extraordinary RNA affinity, binding specificity and stability towards $3^{\prime}$-exonucleases.

Modulation of gene expression by antisense-based approaches continues to stimulate the development of novel chemically modified nucleotides in search of oligonucleotides with improved RNA affinity, binding specificity, and pharmacokinetic profiles. ${ }^{1}$ Of the many modifications studied for antisense applications, conformationally restricted nucleotides, ${ }^{2}$ and locked nucleic acid (LNA) in particular, ${ }^{3}$ have emerged as particularly promising chemistries toward this end. Over the past 15 years, major efforts have been devoted to increase the chemical diversity of LNA nucleotides through additional modification of the sugar ring, with the aim of improving properties for antisense applications., Modification of the nucleobase of LNA, on the other hand, is an underexplored strategy for optimization of pharmacodynamic and pharmacokinetic properties.

Modification of the C5-position of pyrimidines is particularly interesting due to synthetic feasibility and functional group tolerance, as attached moieties are directed into the major groove with minimal perturbation of the duplex structure. ${ }^{5,6}$ We have previously shown that attachment of small hydrophilic moieties to the C5-position of LNA uridine (U) such as 3-aminopropyn-1-yl promotes even greater target affinity than canonical LNA, while attachment of large hydrophobic substituents such as cholesterol confers complete stability against exonucleases, albeit at the expense of decreased target affinity. ${ }^{7}$ At the onset of the present study, we hypothesized that hydrophilic moieties of intermediate size would contribute to both additionally improved affinity and nuclease stability. Furthermore, positively charged moieties often

Department of Chemistry, University of Idaho, 875 Perimeter Drive MS2343, Moscow, ID, 83844-2343, USA. E-mail: hrdlicka@uidaho.edu

$\dagger$ Electronic supplementary information (ESI) available: Synthetic protocols, NMR spectra and MS data for new nucleosides and ONs; thermal denaturation curves; additional $T_{\mathrm{m}}$ and thermodynamic data; sequences of AONs. See DOI: $10.1039 / \mathrm{c} 4 \mathrm{cc} 03623 \mathrm{a}$ improve cellular uptake through electrostatic interactions. ${ }^{8,9}$ Amino acids are a class of molecules that fit the size, hydrophilicity and charge criteria. ${ }^{10}$ Driven by the desire to exploit the properties of both LNA and basic amino acid residues, we report the synthesis of three C5-amino acid functionalized LNA-U phosphoramidites and the biophysical characterization of ONs modified with these units.

Synthesis of phosphoramidites $4 \mathbf{x} / \mathbf{y} / \mathbf{z}$ initiates from known nucleoside 1 (Scheme 1). ${ }^{7}$ Deprotection of the trifluoroacetamide (TFA) group using saturated methanolic ammonia reveals the aminopropynyl group at the C5-position of 2 in 97\% yield. TSTU-mediated coupling of TFA-protected glycine, leucine or lysine gives $3 \mathbf{x} / \mathbf{y} / \mathbf{z}$ in moderate yields (48-58\%). $\$$ Subsequent O3 $^{\prime}$-phosphitylation affords phosphoramidites $\mathbf{4 x} / \mathbf{y} / \mathbf{z}$, which were used for incorporation of monomers $\mathbf{X} / \mathbf{Y} / \mathbf{Z}$ into ONs by automated DNA solid-phase synthesis (15 min, 4,5-dicyanoimidazole as activator, average coupling yield $>90 \%$ ). The composition and

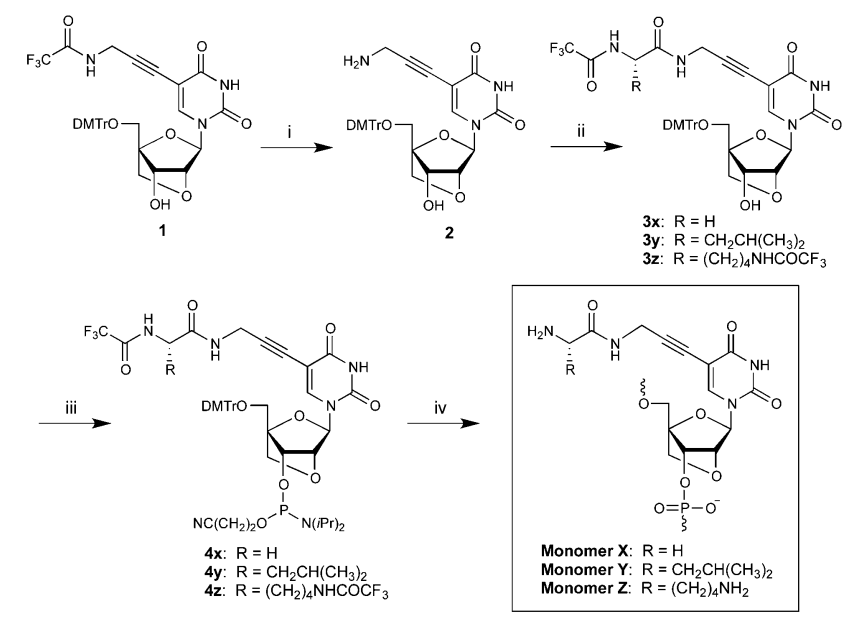

Scheme 1 Reagents and conditions: (i) sat. $\mathrm{NH}_{3} / \mathrm{MeOH}$ (97\%); (ii) TFAprotected amino acid, $N, N, N^{\prime}, N^{\prime}$-tetramethyl-O-(N-succinimidyl)uronium tetrafluoroborate (TSTU), $N, N$-diisopropylethylamine (DIPEA), DMF (48-58\%); (iii) 2-cyanoethyl $\mathrm{N}, \mathrm{N}$-diisopropylchlorophosphoramidite, DIPEA, $\mathrm{CH}_{2} \mathrm{Cl}_{2}$ (37-64\%); (iv) DNA synthesis. DMTr $=4,4^{\prime}$-dimethoxytrityl. 
Table $1 T_{\mathrm{m}}$ 's of duplexes between B1-B4-series and complementary $\mathrm{RNA}^{\mathrm{a}}$

\begin{tabular}{lllllll}
\hline & & \multicolumn{5}{c}{$\Delta T_{\mathrm{m}} / \mathrm{mod}$} \\
\cline { 3 - 7 } ON & Sequence & $\mathbf{B}=\mathbf{L}^{b}$ & $\mathbf{B}=\mathbf{N}^{b}$ & $\mathbf{B}=\mathbf{X}$ & $\mathbf{B}=\mathbf{Y}$ & $\mathbf{B}=\mathbf{Z}$ \\
\hline B1 & 5'-GTG ABA TGC & +8.5 & +13.0 & +10.5 & +9.5 & +12.5 \\
B2 & 3'-CAC BAT ACG & +5.5 & +10.0 & +10.5 & +10.5 & +11.0 \\
B3 & 3'-CAC TAB ACG & +8.5 & +12.5 & +10.0 & +7.0 & +14.0 \\
B4 & 3'-CAC BAB ACG & +7.5 & +11.0 & +10.8 & +9.3 & +13.0
\end{tabular}

${ }^{a} \Delta T_{\mathrm{m}} / \bmod =$ change in $T_{\mathrm{m}}$ per modification relative to unmodified reference duplex (R1:D2 or D1:R2 both $\left.T_{\mathrm{m}}=28.0{ }^{\circ} \mathrm{C}\right)$; R1: $5^{\prime}$-GUG AUA UGC; R2: $3^{\prime}$-CAC UAU ACG; $T_{\mathrm{m}}$ 's determined as the maximum of the first derivative of the melting curve $\left(A_{260} v s . T\right)$ recorded in medium salt phosphate buffer $\left(\left[\mathrm{Na}^{+}\right]=110 \mathrm{mM},\left[\mathrm{Cl}^{-}\right]=100 \mathrm{mM}, \mathrm{pH} 7.0\left(\mathrm{NaH}_{2} \mathrm{PO}_{4} /\right.\right.$ $\left.\mathrm{Na}_{2} \mathrm{HPO}_{4}\right)$ ), using $1.0 \mu \mathrm{M}$ of each strand. Monomer $\mathbf{L}=$ LNA-T. Monomer $\mathbf{N}=$ C5-(3-aminopropyn-1-yl)-LNA-U. ${ }^{b}$ Previously reported. ${ }^{7}$

purity of all modified ONs was ascertained by MALDI-MS analysis (Table S1, ESI $\dagger$ ) and ion-pair reversed-phase HPLC, respectively.

ONs modified with C5-amino acid functionalized LNA-U monomers $\mathbf{X} / \mathbf{Y} / \mathbf{Z}$ display higher affinity toward complementary RNA than ONs modified with canonical LNA thymidine (monomer L) (Table 1). Incorporation of glycine-conjugated monomer $\mathbf{X}$ consistently increases the thermal denaturation temperatures ( $T_{\mathrm{m}}$ 's) of 9-mer mixed-sequence model duplexes by $10-11{ }^{\circ} \mathrm{C}$, while leucine-conjugated monomer $\mathbf{Y}$ results in slightly less thermostable duplexes $\left(\Delta T_{\mathrm{m}}=+7.0\right.$ to $\left.+10.5{ }^{\circ} \mathrm{C}\right)$. ONs containing lysine-conjugated monomer $\mathbf{Z}$ display the highest RNA affinity in this series $\left(\Delta T_{\mathrm{m}}=+11.0\right.$ to $\left.+14.0{ }^{\circ} \mathrm{C}\right)$. In fact, $\mathbf{Z}$ is as affinityenhancing as C5-aminopropynyl LNA-U (monomer N). ${ }^{7}$ Similar trends are observed towards DNA targets, although slightly less pronounced stabilization is observed (Table S2, ESI $\dagger$ ).

Thermodynamic parameters for duplex formation were determined from denaturation curves through curve fitting (Table S3, ESI $\dagger) .{ }^{11}$ Changes in free energy $(\Delta G)$ follow similar trends as $T_{\mathrm{m}}$ 's. Thus, ONs containing monomers $\mathbf{X} / \mathbf{Y} / \mathbf{Z}$ show greater affinity toward RNA than DNA targets (RNA: $\Delta G^{298}=-8$ to $-23 \mathrm{~kJ} \mathrm{~mol}^{-1}$; DNA: $\Delta G^{298}=-5$ to $-17 \mathrm{~kJ} \mathrm{~mol}^{-1}$ ), and greater target affinity than ONs modified with LNA-T. The additional stabilization provided by the C5-amino acid functionalized LNA monomers is a result of more favorable enthalpy. This is likely due to extended $\pi$-conjugation of the nucleobase and improved stacking within the duplex, ${ }^{6 b}$ as well as electrostatic screening of the negatively charged duplex by protonated amino acid residues. ${ }^{6 c-g}$ The latter is a reasonable assumption considering that the $\mathrm{p} K_{\mathrm{a}}$ for $\alpha$-amino groups of free amino acids and the $\varepsilon$-amino group of lysine is $>9.16$ and 10.67 , respectively. ${ }^{12}$

To study in greater detail if protonation of the amino acid residues of monomers $\mathbf{X} / \mathbf{Y} / \mathbf{Z}$ contributes to duplex stabilization, thermal denaturation profiles were recorded in buffers of decreasing ionic strength $(110,40$, and $10 \mathrm{mM}$ sodium phosphate buffer). ${ }^{6 a}$ As expected, lower absolute $T_{\mathrm{m}}$ 's are observed at low ionic strengths due to decreased electrostatic shielding of the two negatively charged duplex strands (Tables S4 and S5, ESI $\dagger$ ). Interestingly, ONs modified with monomers $\mathbf{X} / \mathbf{Y} / \mathbf{Z}$ show greater relative affinity increases toward RNA and DNA targets at lower ionic strengths as evidenced by the trend in $\Delta T_{\mathrm{m}}$ 's (Fig. 1 and Fig. S2, ESI $\dagger$ ). For example, the $\Delta T_{\mathrm{m}}$ for the duplex

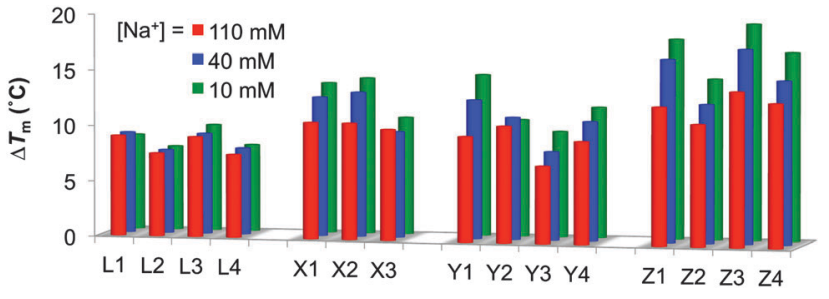

Fig. 1 Thermostabilities of duplexes between B1-B4-series and RNA at different ionic strengths. $\Delta T_{\mathrm{m}}=$ change in $T_{\mathrm{m}}$ 's relative to unmodified reference duplex D1:R2 $\left(T_{\mathrm{m}, 110 \mathrm{mM}}=28.0{ }^{\circ} \mathrm{C}, T_{\mathrm{m}, 40 \mathrm{mM}}=21.0{ }^{\circ} \mathrm{C}, T_{\mathrm{m}, 10 \mathrm{mM}}=\right.$ $\left.11.5^{\circ} \mathrm{C}\right)$; R1:D2 $\left(T_{\mathrm{m}, 110 \mathrm{~mm}}=28.0{ }^{\circ} \mathrm{C}, T_{\mathrm{m}, 40 \mathrm{mM}}=22.0^{\circ} \mathrm{C}, T_{\mathrm{m}, 10 \mathrm{mM}}=12.0^{\circ} \mathrm{C}\right)$. Buffer conditions: $\left[\mathrm{Na}^{+}\right]=110 \mathrm{mM}$ and $\left[\mathrm{Cl}^{-}\right]=100 \mathrm{mM} ;\left[\mathrm{Na}^{+}\right]=40 \mathrm{mM}$ and $\left[\mathrm{Cl}^{-}\right]=30 \mathrm{mM} ;\left[\mathrm{Na}^{+}\right]=10 \mathrm{mM}$. pH $7.0\left(\mathrm{NaH}_{2} \mathrm{PO}_{4} / \mathrm{Na}_{2} \mathrm{HPO}_{4}\right)$ in all cases. See also Table S4 (ESI†).

between lysine-modified $\mathrm{Z1}$ and complementary RNA is $12.5{ }^{\circ} \mathrm{C}$ and $18.0{ }^{\circ} \mathrm{C}$ at $\left[\mathrm{Na}^{+}\right]=110 \mathrm{mM}$ and $10 \mathrm{mM}$, respectively (Table S4, ESI $\dagger$ ). These effects are much weaker for LNA-modified ONs (L1-L4), which strongly suggests that the C5-amino acid moieties of monomers $\mathbf{X} / \mathbf{Y} / \mathbf{Z}$ indeed are protonated and contribute to duplex stability. ${ }^{6 a}$

The specificity of ONs modified with C5-amino acid functionalized LNA-U monomers $\mathbf{X} / \mathbf{Y} / \mathbf{Z}$ was evaluated by measuring the $T_{\mathrm{m}}$ 's of duplexes between modified ONs and RNA or DNA containing a mismatched nucleotide either directly across from the central modification (B1-series) or 2'-deoxyadenosine (B4-series). Just like LNA-T (L1) or C5-aminopropynyl modified (N1), X1/Y1/Z1 show comparable or improved discrimination of mismatched RNA and DNA relative to D1 (Table 2 and Table S6, ESI $\dagger$ ). Discrimination of the challenging $\mathrm{T} / \mathrm{U}: \mathrm{G}$ mismatch is particularly effective. Doubly modified $\mathbf{X 4 / Y 4 / Z 4 ~ a l s o ~ d i s c r i m i n a t e ~ m i s m a t c h e d ~ R N A ~ t a r g e t s ~}$ well, whereas discrimination of mismatched DNA targets is far less efficient (Table S7, ESI $\dagger$ ). The latter may be a result of stabilizing non-specific electrostatic interactions occurring in DNA duplexes.

ONs with C5-amino acid functionalized LNA-U monomers positioned close to the 3 '-terminus $(\mathbf{X} 2 / \mathbf{Y} 2 / \mathbf{Z 2})$ were evaluated for nuclease stability using snake venom phosphodiesterase (SVPDE), a $3^{\prime}$-exonuclease (Fig. 2). As expected, unmodified DNA (D2) is completely cleaved within $40 \mathrm{~min}$. Incorporation of a single LNA-T (L2) still results in complete digestion, although at a significantly slower rate. Satisfyingly, $\mathbf{X 2 / Y 2 / Z 2 ~ w e r e ~ c o m p l e t e l y ~ s t a b l e ~ t o ~}$ SVPDE once degradation of the $2-3$ terminal 2 -deoxyribonucleotides

Table 2 Thermal discrimination of mismatched RNA targets by $\mathbf{B} \mathbf{1}$-series ${ }^{\mathbf{a}}$

\begin{tabular}{|c|c|c|c|c|c|}
\hline \multirow[b]{3}{*}{$\mathrm{ON}$} & \multirow[b]{3}{*}{ Sequence } & \multicolumn{4}{|c|}{ RNA: 3'-CAC UMU ACG } \\
\hline & & \multirow{2}{*}{$\frac{T_{\mathrm{m}}\left({ }^{\circ} \mathrm{C}\right)}{\mathbf{M}=\mathbf{A}}$} & \multicolumn{3}{|l|}{$\Delta T_{\mathrm{m}}\left({ }^{\circ} \mathrm{C}\right)$} \\
\hline & & & $\mathbf{M}=\mathbf{C}$ & $\mathbf{M}=\mathbf{G}$ & $\mathbf{M}=\mathbf{U}$ \\
\hline D1 & 5'-GTG ATA TGC & 28.0 & $<-18.0$ & -5.5 & $<-18.0$ \\
\hline $\mathbf{L 1}^{b}$ & 5'-GTG ALA TGC & 36.5 & -20.0 & -9.0 & -19.5 \\
\hline $\mathbf{N} 1^{b}$ & $5^{\prime}$-GTG ANA TGC & 41.0 & -18.5 & -11.5 & -22.5 \\
\hline X1 & $5^{\prime}$-GTG AXA TGC & 38.5 & -17.0 & -11.5 & -19.0 \\
\hline Y1 & $5^{\prime}$-GTG AYA TGC & 37.5 & -16.0 & -9.0 & -19.0 \\
\hline $\mathbf{Z 1}$ & $5^{\prime}$-GTG AZA TGC & 40.5 & -17.0 & -11.5 & -19.0 \\
\hline
\end{tabular}

${ }^{a} \Delta T_{\mathrm{m}}=$ change in $T_{\mathrm{m}}$ relative to fully matched $\mathbf{B 1 : R 2}$ duplex $(\mathbf{M}=\mathbf{A})$ shown in bold. ${ }^{b}$ Previously reported. ${ }^{7}$ 


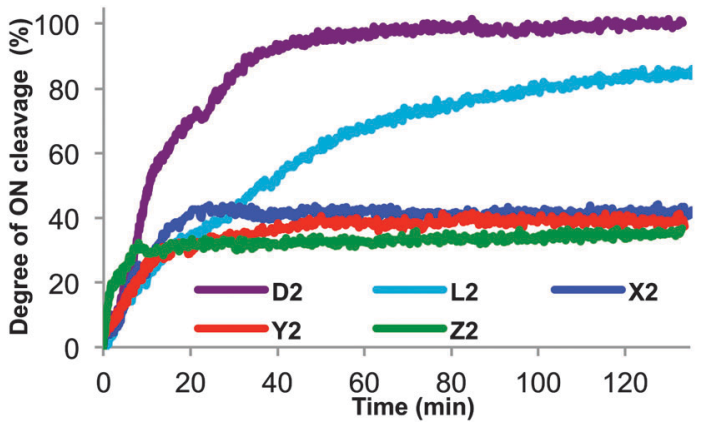

Fig. 2 Enzymatic degradation of $\mathbf{B 2}$-series by $\mathbf{3}^{\prime}$-exonuclease (SVPDE) performed in magnesium buffer ( $50 \mathrm{mM}$ Tris- $\mathrm{HCl}, 10 \mathrm{mM} \mathrm{Mg}^{2+}, \mathrm{pH}$ 9.0) by using $3.3 \mu \mathrm{M}$ ONs and $0.52 \mu \mathrm{g}(0.03 \mathrm{U})$ of SVPDE at $37^{\circ} \mathrm{C}$. Degree of ON cleavage calculated as the change in absorbance at $260 \mathrm{~nm}$ with respect to unmodified DNA $\left[\left(A_{260}(\mathbf{B} 2)-A_{260, \text { initial }}(\mathbf{B} 2)\right) /\left(A_{260, \text { final }}(\mathbf{D} 2)-A_{260, \text { initial }}(\mathbf{D} 2)\right)\right]$.

had ceased, as evidenced by the plateau in their degradation profiles.

Encouraged by these results, we designed a fully phosphorothioated 3-14-3 gapmer antisense ON (ASO) targeting firefly luciferase mRNA (Table S8, ESI $\dagger$ ). Very preliminary experiments using murine 3T3-L1 cells indicate that ASOs modified with two C5-lysine LNA-U Z monomers, one in each LNA wing, display similar knockdown efficiency ( $\sim 50 \%$ at $80 \mathrm{nM}$ ), with no observable cell death, as the corresponding ASO with LNA-T when cationic transfection agents are used (results not shown). Additional studies are necessary to assess the full potential of C5-amino acid functionalized LNA-U monomers as ASO modifications, including their promise for enhanced and/or gymnotic ASO delivery.

In summary, C5-amino acid functionalized LNA uridine phosphoramidites represent a novel approach to chemical diversification of LNA. ONs containing monomers $\mathbf{X} / \mathbf{Y} / \mathbf{Z}$ display significantly higher affinity toward complementary RNA than canonical LNA ONs due to extended conjugation of the nucleobase, as well as stabilizing electrostatic interactions. The excellent specificity of LNA modified ONs towards singly mismatched RNA is maintained. Additionally, monomers $\mathbf{X} / \mathbf{Y} / \mathbf{Z}$ are inert towards enzymatic digestion by $3^{\prime}$-endonuclease (SVPDE), which sets them apart from other high-affinity C5-LNA-U monomers. ${ }^{7}$ The promising biophysical properties and cationic character render C5-amino acid functionalized LNA positively poised for antisense applications.

We appreciate financial support from the National Institute of General Medical Sciences, National Institutes of Health (award number GM088697), and NIH Grant \#P20 RR016454 from the INBRE Program of the National Center of Research Resources and P20 GM103408 (National Institute of General Medical Sciences). We thank the EBI Murdock Mass Spectrometry Center and Lee Deobald (Univ. Idaho) and Michael Østergaard
(Isis Pharmaceuticals) for MS analysis, Alex Blumenfeld (Univ. Idaho) for NMR analysis, and Deep Pokharel and Rod Hill (Univ. Idaho) for advice on cell culture studies.

\section{Notes and references}

$\$$ For an alternative synthesis of compound 2, see ESI. $\dagger$

$\S$ Coupling between Fmoc-protected amino acids and 2 was unsuccessful.

1 For reviews see: (a) S. M. Freier and K.-H. Altmann, Nucleic Acids Res., 1997, 25, 4429; (b) C. F. Bennett and E. E. Swayze, Annu. Rev. Pharmacol. Toxicol., 2010, 50, 259; (c) G. F. Deleavey and M. J. Damha, Chem. Biol., 2012, 19, 937.

2 For reviews see: (a) S. Obika, S. M. A. Rahman, A. Fujisaka, Y. Kawada, T. Baba and T. Imanishi, Heterocycles, 2010, 81, 1347; (b) C. Zhou and J. Chattopadhyaya, Chem. Rev., 2012, 112, 3808; (c) P. P. Seth and E. E. Swayze, in Natural Products in Medicinal Chemistry, ed. S. Hanessian, Wiley-VCH, Weinheim, 1st edn, 2014, pp. 403-439.

3 (a) S. K. Singh, P. Nielsen, A. A. Koshkin and J. Wengel, Chem. Commun., 1998, 455; (b) S. Obika, D. Nanbu, Y. Hari, J.-I. Andoh, K.-I. Morio, T. Doi and T. Imanishi, Tetrahedron Lett., 1998, 39, 5401; (c) H. Kaur, B. R. Babu and S. Maiti, Chem. Rev., 2007, 107, 4672.

4 For recent examples see: (a) Y. Hari, T. Morikawa, T. Osawa and S. Obika, Org. Lett., 2013, 15, 3702; (b) M. T. Migawa, T. P. Prakash, G. Vasquez, P. P. Seth and E. E. Swayze, Org. Lett., 2013, 15, 4316; (c) S. Hanessian, J. Wagger, B. L. Merner, R. D. Giacometti, M. E. Østergaard, E. E. Swayze and P. P. Seth, J. Org. Chem., 2013, 78, 9064; (d) A. R. Shrestha, Y. Kotobuki, Y. Hari and S. Obika, Chem. Commun., 2014, 50, 575.

5 For reviews see: (a) I. Luyten and P. Herdewijn, Eur. J. Med. Chem., 1998, 33, 515; (b) M. Ahmadian and D. E. Bergstrom, in Modified Nucleosides in Biochemistry, Biotechnology and Medicine, ed. P. Herdewijn, WileyVCH, Weinheim, 1st edn, 2008, pp. 251-276.

6 For representative examples see: $(a)$ H. Hashimoto, M. G. Nelson and C. Switzer, J. Am. Chem. Soc., 1993, 115, 7128; (b) R. W. Wagner, M. D. Matteucci, J. G. Lewis, A. J. Gutierrez, C. Moulds and B. C. Froehler, Science, 1993, 260, 1510; (c) H. Nara, A. Ono and A. Matsuda, Bioconjugate Chem., 1995, 6, 54; (d) M. Ahmadian, P. M. Zhang and D. E. Bergstrom, Nucleic Acids Res., 1998, 26, 3127; (e) L. E. Heystek, H. Q. Zhou, P. Dande and B. Gold, J. Am. Chem. Soc., 1998, 120, 12165; $(f)$ V. Roig and U. Asseline, J. Am. Chem. Soc., 2003, 125, 4416; $(g)$ J. Booth, T. Brown, S. J. Vadhia, O. Lack, W. J. Cummins, J. O. Trent and A. N. Lane, Biochemistry, 2005, 44, 4710; (h) T. Kottysch, C. Ahlborn, F. Brotzel and C. Richert, Chem. - Eur. J., 2004, 10, 4017.

7 P. Kumar, M. Østergaard, B. Bharal, B. A. Anderson, D. C. Guenther, M. Kaura, D. J. Raible, P. K. Sharma and P. J. Hrdlicka, J. Org. Chem., 2014, 79, 5047.

8 F. Debart, S. Abes, G. Deglane, H. M. Moulton, P. Clair, M. J. Gait, J.-J. Vasseur and B. Lebleu, Curr. Top. Med. Chem., 2007, 7, 727.

9 For recent examples see: (a) G. Deglane, S. Abes, T. Michel, P. Prevot, E. Vives, F. Debart, I. Barvik, B. Lebleu and J.-J. Vasseur, ChemBioChem, 2006, 7, 684; (b) M. Park, D. Canzio and T. C. Bruice, Bioorg. Med. Chem. Lett., 2008, 18, 2377; (c) K. T. Gagnon, J. K. Watts, H. M. Pendergraff, C. Montaillier, D. Thai, P. Potier and D. R. Corey, J. Am. Chem. Soc., 2011, 133, 8404.

10 (a) M. W. Johannsen, L. Crispino, M. C. Wamber, N. Kalra and J. Wengel, Org. Biomol. Chem., 2011, 9, 243; (b) J. Lietard, D. Ittig and C. J. Leumann, Bioorg. Med. Chem., 2011, 19, 5869; (c) K. Mori, T. Kodama, T. Baba and S. Obika, Org. Biomol. Chem., 2011, 9, 5272. 11 J. L. Mergny and L. Lacroix, Oligonucleotides, 2003, 13, 515.

12 Handbook of Chemistry and Physics, ed. D. R. Lide, CRC Press, Boca Raton, 87th edn, 2006, p. 7-1. 